\title{
The Power and Possibilities for Understanding Teaching in these Times with Ethnodramatic Inquiries into Teacher Stories: Two Reviews
}

\author{
Sarah R. Hobson ${ }^{1}$ \\ SUNY Cortland \\ sarah.hobson@cortland.edu
}

\begin{abstract}
The following is a review and commentary on two of Charles Vanover's ethnodramatic performances of the ethnographic interviews of two teachers. At two sessions at two educational conferences, Charles staged verbatim excerpts from each interview to open conversations with teacher educators about the challenges faced by two teachers in Chicago Public Schools. With this review, I explain the structuring behind each performance and the ensuing conversations about teacher challenges and needs in these times. I illuminate how educators can use ethnodramatic inquiries into teacher stories to deepen their understandings of teacher education and to re-write narratives that scapegoat teachers as the problem.
\end{abstract}

Keywords: ethnodrama; practitioner inquiry; art-based research; teacher education; educational policy

\footnotetext{
${ }^{1}$ Biographical statement: Dr. Sarah Reed Hobson is an Assistant Professor in Adolescence English Education at The State University of New York at Cortland. She received her Ph.D. in Reading, Writing, and Literacy from the Graduate School of Education at the University of Pennsylvania. While completing her doctorate, she designed, implemented, and researched a number of in-school, content-specific elective classes utilizing drama, playwriting, and ethnodrama. She has expanded her implementation and research with a recent after-school program in St. Louis, introducing junior and senior high school students to ethnodramatic filmmaking.
} 
The following is a review and commentary on two ethnodramatic performances of the ethnographic interviews of two teachers. The first performance and talk back, titled Goodbye to All That!: An accomplished teacher's last year in the Chicago Public Schools (Vanover, 2014), took place on April 5, 2014 at the Asian Arts Initiative. The second, Listening to the Silences: Stories of a Teacher's First Year ${ }^{2}$ (Vanover, 2015), took place on February 28, 2015 at the 36 Annual Ethnography in Education Research Forum at the University of Pennsylvania.

\section{Two Examples of Ethnodramatic Inquiry}

In the past two years, I have been a part of two different efforts of Charles Vanover's to feature two different teachers' stories from their years in Chicago public schools. These stories were intended to provoke honest conversations among teachers and teacher educators about the complexities of teaching in our current era and about the role of teacher educators in understanding these complexities and finding ways to support teachers. In the process of engaging two different audiences, we also found ourselves grappling with the danger of these teachers' stories becoming re-appropriated into dominant critiques of teachers. The teachers Vanover interviewed worked in a city system that had been shaped by neo-liberal education policies. By creating a safe space for teachers to talk about their concerns and their problems during the interview sessions that were the foundation of his ethnodramatic work, the teachers who told him their stories became vulnerable to criticism.

\section{Goodbye to All That! 2014.}

I first saw Charles Vanover's work in 2014 at the Ethnography Forum. During the performance of Goodbye to All That! I sat in the audience, captivated by the show that came to life. As a designer of ethnodramatic pedagogy, I was mesmerized by the complex story Addison, a white, veteran Chicago teacher, told about her years in a predominantly Hispanic inner city school, situated in a neighborhood known for having endured many violent incidents. In the ethnodrama, after painting a picture of two of her students fighting to stay in school and to succeed despite tremendous odds, Addison recounted her efforts to teach to her $7^{\text {th }}$ graders Paula Fox's novel The Slave Dancer. The novel tells the story of a white boy from New Orleans who is kidnapped and forced to work on a slave ship across the middle passage with a cargo of kidnapped Africans. As relayed in the ethnodrama, Addison's teaching of this novel was dynamic and interactive. She and the students researched the dimensions of the hold of the ship where the slaves were held. They researched everything they could find about the middle passage. They made connections to current day slavery. They inquired into the cultural reasons for slavery. They discussed the multiple

\footnotetext{
${ }^{2}$ Charles Vanover's article in this issue presents the script for this performance and his commentary on producing the script.

The Power and Possibilities for Understanding Teaching in these Times with Ethnodramatic Inquiries into Teacher Stories: Two Reviews
} 
dimensions of conflicts the slaves encountered on and off the ship, and much more.

Charles Vanover staged the ethnodrama with three university readers/actors. Alexandra Miletta performed Addison, while Brandi Weekly read sections from the novel. K. Nicola Williams served as the voice of Charlotte, a struggling student. The performance that took place at the Ethnography Forum so captivated me that I signed on to work as the facilitator for an off-site performance of the show that took place about a month later in Chinatown, at Asian Arts Initiative. This second show drew an audience from the Annual Conference of the American Educational Research Association, which was in Philadelphia that year. The Chinatown performance used the same performers except that Vasey Coman, a Master's student at the University of Pennsylvania, played the part of Addison's student, Charlotte.

In attendance at the Asian Arts Initiative performance were eight educational researchers, a group of former teachers, and principals from both the United States and South Africa, and teacher educators from a range of states. The performance was divided into two parts. Before the performance, we organized a set of large sheets of paper with questions I had designed, posted around the room. With these questions, I hoped to open a discussion about the possibilities and obstacles to teaching in inner city schools. I also intended for us to learn from Addison about the challenges and possibilities of a classroom centered in researching systems of power and privilege together with students from many cultural backgrounds. The questions were the following:

- What are you learning about Chicago schools?

- What are you learning about the resources available to teachers?

- What are you learning about the obstacles to making a difference?

- What are you learning about cultural disconnects among teachers and students?

- What actions can we take to support teachers and students?

- How can we better prepare teachers to connect meaningfully with students?

We also had a blank sheet for any additional thoughts or questions. I invited everyone to introduce themselves and to take note of the questions, around which we would reflect and open a discussion during the intermission.

Charles Vanover then framed the show, explaining Addison's history as an inner city teacher who had left one of the city's premier magnet schools and found herself in one of Chicago's toughest schools, for reasons never clearly discussed in her narrative. Addison taught some of the most vulnerable and deserving students in that school building, many of whom had experienced years of failure in the system, but she received no special status or acclaim for doing 
that work. He invited us to consider two questions as we watched: How is teaching an act of care? Can you go too deep in teaching?

During the first half, Alexandra Miletta performed Addison's stories about two struggling students and her efforts to advocate for them and their needs, amidst administrators who would not work with her. For example, she expressed her agony over knowing her student Charlotte wanted to be in school and off of the streets for the summer; however, Charlotte's test scores were too high for summer school, and thus by succeeding in school, Charlotte was deprived of resources that would have supported her learning. Addison described her deep connection to the students' communities, a prerequisite to teaching; she ranted about her burn out, her struggles to connect with $7^{\text {th }}$ graders, when she felt better equipped to teach primary and intermediate students; and her fears that she was no longer learning, pushing herself to grow as a teacher. Addison had given ten years of her life to teaching. She was teaching vulnerable students who deserved her expertise, and she walked out of school every day feeling tired, frustrated, and angry.

At the intermission, after participants had refreshments and wrote their reactions on the sheets of paper, I facilitated a discussion that began with the question: "What stands out to you?" Slowly and thoughtfully, the participants shared a range of reactions that touched on Addison's need to step back, refresh, find room to reflect on her practice and its multiple dimensions with mentors and colleagues, and establish her own system for managing each of those dimensions. In particular, an inquiry emerged into Addison's observation that she no longer felt like she was growing as a teacher. We worked together to qualify what counted as growth and what kind of infrastructure she would need in and around her practice to find room to grow in the way she desired. We considered her constant need to advocate for students amidst the obstacles presented by the school as working against her pursuit of time to process her practice.

The second half of the performance was emotionally tough. Brandi Weekley's reading from The Slave Dancer included vivid details of torture and agony, descriptions of the racial and class hierarchies and degrees of privilege and vulnerability aboard the slave ship. Alexandra Miletta's performance of Addison included carefully scaffolded learning opportunities for the $7^{\text {th }}$ graders, who found room to both ask and to research a range of questions about past systems of slavery and about slavery in various countries today. While Addison's work did not yet exist in an educational era in which the US national "Common Core" curriculum standards require the teaching of a broader range of historical and informational texts, Addison had incorporated a range of texts and projects that helped students research both the narrative structure of the novel as well as the historical and cultural practices of the time. 
The discomfort elicited by the content of The Slave Dancer left participants in shocked silence, not sure how to respond, somewhat overwhelmed by the raw historical truth the novel's author, Fox, offered her readers. The music Andrew Babson played for the performance amplified this discomfort. After the show, Andrew commented that he composed the score from techno recordings by artists, such as Jeff Mills and Archetype, all of whom had grown up in multicultural neighborhoods in the Midwest. The tracks were violent, and their beats were intended to communicate the feeling of working in a room crowded with students who had been rejected by their school and their neighborhood. At the end of the ethnodrama, when Addison described how her yoga practice called her to walk away from the students she served, and eventually leave the Chicago Public Schools, the score became smoother and more melodic. The music seemed to offer Addison release from her labor. Such a release was problematic because the challenges of the system remained; Addison had left her students to be taught by whomever the system put in her place.

Following the performance, since the show had started late due to technical difficulties with the sound equipment, I found myself under pressure to wrap up our time together, realizing that our audience had a wide variety of reactions and insights into what they had witnessed, but that they were also tired and the hour was late. In the second half of the performance, we learned specifically about Addison's efforts to use literature to engage students in processing difficult understandings around slavery. In response, I briefly reintroduced one of Vanover's framing questions for the performance: Was this an example of going too deeply into the issue of slavery with $7^{\text {th }}$ graders?

The audience talked for 20 minutes, providing a range of beliefs about the degree to which teaching this novel was appropriate. One woman was adamant that teaching such topics would cause students to dwell on issues that could reinscribe social injuries in the classroom and lead to depression. Indeed, the risky nature of Addison's teaching, and the way she dealt-at times casually-with descriptions of teaching that likely had deeply personal implications for students, led to much uncertainty for all of us about the way Addison was handling the messages students might be receiving. These questions were never resolved.

There was so much from the play I wanted to go over, but it was late and we had to leave. Thus, to end, I posed a few more questions raised by the ethnodrama regarding what this kind of teaching could do to help address the societal inequities the students were living, and invited everyone to consider how else Addison could develop her practice to better support student inquiries and needs. With my questions, I proposed that she had stopped short of creating room for students to inquire into past and present systemic practices of slavery that influenced their immediate lives. I have to say, audience responses rang hollow. The teacher in the ethnodrama, along with describing a novel study that this audience felt was problematic, described teaching challenges that felt unsolveable. She described historical forces that touched her students' lives, but 
were rarely recognized by her school system's administrators. By beginning with her kids and following their needs and interests, and speaking honestly about her teaching, Addison had become vulnerable to our criticism. The emotion created by the performance was difficult to manage.

As we packed up to leave, Brandi, Alexandra, and I found one another and began to process both what we had seen and what the audience members had shared. Our heads were spinning with a desire to understand how we could better engage audiences in inquiring productively together into ways to help students process their lives and gain agency within the systems that at times worked against them. I had intended for the questions I initially posed to help us situate Addison's instructional choices and goals within deeper understandings of the resources available to her, as well as the systemic obstacles impeding her desires. I was struck by how the text taken up in the ethnodrama, The Slave Dancer, and the framing questions had surfaced different perspectives and different approaches to teaching. The question for me was how all actors, facilitators, and members present at the performance could better galvanize our perspectives and reactions to facilitate a richer analysis of the strengths of and possibilities for Addison's practice that would help her grow and connect more deeply with her students. I also wondered how together we could better articulate the cultural environment in the school as it supported and impeded her instructional goals.

In the ethnodrama, Addison was present with the kids. The work she was doing was powerful, and she needed support. I wanted to figure out how I could connect with teachers like her to make a positive difference in their lives and the lives of their students. I wondered what kind of common language or frameworks for teaching we might begin with in order to accomplish such goals. As a teacher educator, living daily with a wide variety of questions about improving teaching, I found myself hungry for more examples of teacher practices to unpack with others.

\section{Listening to the Silences 2015.}

In the second year I joined Charles Vanover's effort to open productive conversations about teaching through an ethnodramatic reading of a teacher's interview, more questions were raised. The performance of Listening to the Silences took place as a session focused on educational research at the February, 2015 Ethnography in Education Forum Conference at the University of Pennsylvania in Philadelphia, Pennsylvania. The story of the ethnodrama was about a first year teacher, Indiana; she was white, teaching in a predominantly black inner city school. The story was much softer than Goodbye to All That!, and the music created a different feeling. Vanover used Arvo Pärt's Frates (1977) to comment on the script. Kisha Barr, a working actor, and herself a new inner city teacher of three years, performed Indiana. Jenna Lam performed the role of an interviewer. K. Nicola Williams, a Faculty Associate at Johns Hopkins University 
and the district recruiter for certified staffing and minority recruitment at a large school district in Maryland, served as the discussant and expert on culturally relevant pedagogy for the session. Andrew Babson, a lecturer in education at the University of Pennsylvania, and I served as co-chairs.

With this ethnodrama, Charles Vanover had made the decision to situate the audience in a similar position to Indiana. He wanted the audience to experience the tumult of Indiana's circumstances as a new teacher and throw them into her classroom in the way that Indiana had been thrown into her teaching position at the school. Furthermore, Indiana reflected with such depth and insight into her first year, he felt her story needed less framing. Thus, we did not employ sheets of paper, framing questions, nor even a description by him of the performance, of Indiana's life, or of what the audience could expect to see. People walked into the conference room, Pärt's music began to play, and about five minutes into the final conference slot of the final day of the Ethnography in Education Forum, Kisha Barr, the actor playing Indiana, got out of her seat in the audience and the show began.

Indiana came across to me as a wide-eyed teacher, unpacking layers upon layers of her practice: her inquiries into students and their lives, her relationship building efforts with students, and the lengths she had gone to in order to connect with them and to encourage them as readers and writers. She could articulate the exact reading and writing workshops she had designed, the kinds of struggles her students had presented as readers and writers, and her strategies to feature and celebrate their work that had resulted in students deciding to write and write and write. Indiana could articulate the questions she had about how to teach $5^{\text {th }}$ grade students with $3^{\text {rd }}$ grade reading abilities and how to encourage and engage adolescent students who had been held back for years. The beginning teacher shared about how her eyes were being opened to the realities of her students' lives. She had carefully noted the deepening silence of one of her students over the course of the year, and she had worked to get to know her students by providing them a safe space before and after school where they could "hang" with her. When her students needed supplies, Indiana bought them. When her students needed a ride, she drove them home. There were also questions she had not yet learned to ask, such as, how to help students use reading and writing to process the violence they were experiencing. She also stopped short of intimately connecting with their communities and their realities.

The audience had been given programs that contained long excerpts from Indiana's interview (see Vanover, 2016). At the conclusion of the ethnodrama, Charles Vanover told the audience to look over those programs and then to talk amongst themselves in small groups. He said he would pull the group together in 10 or 15 minutes, and then he walked out of the room, and left the audience to manage on its own. We talked for 15 minutes and a whole new inquiry emerged as a result of his decision to engage the audience in a completely open conversation - no framing provided. 
My doctoral advisor, Dr. Susan L. Lytle from the University of Pennsylvania was present. She had overseen my dissertation on Fostering Critical Literacy through Ethnodrama with High School Students (Hobson, 2012). An integral founder of practitioner inquiry, I knew her to be keenly attuned, at all times, to respecting the work of teachers. In our ten-year relationship, I had learned from teaching and researching with her and my doctoral colleagues, the power of re-envisioning teaching and learning through systematic and continuous research and reflection on our assumptions about our practices and student identity needs (Lytle \& Cochran-Smith, 1992). When the performance was over, she was eager to learn, and also a bit worried about what the performance was meant to do for us and what the audience was meant to bring to the performance. She wondered why there had been no framing and what made the presentation ethnodrama.

Charles Vanover came back into the room and spent the next five minutes speaking quietly to the actors. The audience was very engaged in discussing the show, and he was not the center of their attention. Eventually, he let the audience conversations draw to a close. He stood up and asked people to speak. Susan Lytle asked him about the lack of framing and asked him to explain the purpose of the performance. In an attempt to answer her questions, Charles Vanover explained that he wanted the audience to experience the confusion and need for fast processing that Indiana faced when learning how to organize herself and her practice within a neighborhood and a school that were unpredictable and foreign to her. K. Nicola Williams, session discussant, had read Charles Vanover's accompanying paper, and she attempted to further the conversation by recounting the argument he had presented in that paper.

As she read sections of his analysis of Indiana's interview from the paper, I cringed. Charles had done what collaborative ethnodramatists in my tradition do not do. Through the performed script, he had re-presented sections of Indiana's verbatim words with the intention of opening productive conversations with an audience about the issues at hand. Nicola held the conference title of "discussant," and in this role, she dutifully oriented towards traditional attendee expectations for a formal analysis of the work presented. By inviting Nicola to serve as "discussant" and to refer to his analysis, Charles risked circumventing that open-ended discussion and the learning with and from the audience. Charles' analysis of his research participant's interview presented a fixed set of interpretations about what her story revealed about her missed opportunities and what was lacking from her teacher education program. He oscillated between noting her strengths and noting her weaknesses as a new teacher, noting what her teacher education program had provided and noting what the teacher said was missing. Charles acknowledged that listening to teachers' stories was a radical and challenging act. For him, the focus of critique was on the system and the brute reality of teaching and learning within classrooms that served students 
of color, staffed with beginning teachers who, by their own accounts, did not understand the students they serve and were learning to teach by teaching.

As the paper being discussed moved back and forth between these analyses, I saw my advisor agonizing over whether to stay or leave. I knew her empathy for teachers and saw her frustration at what I imagined came across to her as deficit perspectives launched at both teachers and teacher education programs. Susan did not walk out, and as soon as Dr. Williams had finished, I provided an alternative response. I shared that Indiana's story conjured up for me my own first year as a teacher and how much I had learned - a recurring theme of Indiana's. I explained how many questions I had had about teaching, about connecting with students, about monologic versus dialogic teaching, about critical pedagogy, but that I had not yet had the understandings to begin to pursue answers. Indiana did not have the experience either. However, Indiana had the ability to reflect and to ask questions, to get to know her students, their realities and their communities. And Indiana was reaching for her own language to help her make sense of these multiple dimensions of education. I commented on the incredible layers I found in Indiana's reflections, and how, when I was a new teacher, no one asked me to write or share or process my questions. I never stopped thinking about my students' lives, but I had no system for organizing my thoughts or for connecting with other teachers who were doing the same. Like Indiana, I was isolated and on my own, reaching for ideals without the help of others to think with me. By my fifth year, I could no longer sleep.

That aloneness was an issue for me throughout my time in a high school classroom. If I have learned one thing from my life as a teacher educator, it is that teachers need a research community; they need collaborators. I loved teaching, I loved my students, but I will never know what I might have done if I had had a community of teachers behind me in the classroom and a principal who passionately believed in and invested in our work. I understand that my aloneness was a product of the neoliberal reforms aimed at commodifying teachers' work and controlling their labor, but given the intensification of these reforms, finding a way to position myself between the teacher that I was and the teachers I hope all teachers might be, has continued to be difficult.

At the Ethnography in Education Forum, that day, I offered that there was not one way of reading a text; there were many and that these performances were intended to open conversations about teaching. As I finished speaking, Susan took the floor, needing to leave and wanting desperately to raise a question for Charles. The session was coming to a close, people had had a half hour to speak either in small groups or as a full audience, and they still had more to say. Susan said that if ethnodrama was about gathering more perspectives, opening more conversation, then the question at hand was: How do we use these ethnodramas productively so that we do not re-inscribe dominant negative narratives about teachers and teacher education? She asked him: "In what contexts will you use these ethnodramas and to what ends?" 
Charles explained that he had created the plays from parts of the interviews that meant the most to him and that he did not understand her question. The performances created from these materials were very meaningful to him. He learned from the interviews through the process of writing the script, putting up the shows and from the dialogue they created. He did not speak long in reply, and he let other people in the room respond to Susan.

Because the room was filled with university teacher educators, we found ourselves processing what Indiana's story revealed to us individually and collectively about the dimensions of teaching that were incumbent upon us as educators to address within and across our programs. I worked to create room for Kisha Barr, the actor who played Indiana in the show, to share with us the ways Indiana's story resonated with her and what she had learned from her first years as a teacher that could inform teacher education programs. Kisha Barr said the play spoke honestly to her about teachers' experiences. She had worked as a teacher for three years, and then had left the classroom to work as an actor. She said, by coincidence, she had taken on a classroom position the week before. We also debated the extent to which academic concepts about the various dimensions of teaching (i.e., teaching frameworks for literacy; language acquisition; dialogic versus monologic teaching; participation structures) could help Indiana before entering the field. We noted that the understanding Indiana already had was conveyed in a way that was less jargony and more real for her and for outside audiences, than was the less accessible academic theory. We also noted the concepts we had acquired from our studies in the university that may have been useful for her in processing the aspects of her practice. We considered that Indiana's raising of questions from her teaching experiences, could lead her to develop her own knowledge-base versus teacher education programs' attempts to front-load academic theories through which to interpret her instructional designs. We inquired into kinds of reflective opportunities we could provide her in and outside of our programs.

Our conversation ran long. There was a break between the last session of the conference and the final keynote. Our conversation had consumed much of that time. First one person got up to leave, and then another and what these absences heightened was a desire to work together to take up the layers of inquiry we had generated. After Charles Vanover formally ended the session, several people lingered to continue talking past the time allotted. He had been open to all feedback; he was eager to learn with everyone where these ethnodramatic performances could go. I had five minutes following the conversation to connect with him. He walked me to my car, after telling the actors to take a break; the three of them would break down the set when he returned.

As we walked, I took him by the shoulders, doing my best to lock him into hearing and understanding my words. I suddenly had an epiphany. Charles Vanover is from an educational administrative background. I am from a literacy

The Power and Possibilities for Understanding Teaching in these Times with Ethnodramatic Inquiries into Teacher Stories: Two Reviews 
background. We are working hard to find a way to connect across our different disciplines in order to help education move in productive directions on behalf of teachers and students. I wondered: How, in five minutes, can I help him understand the different dimensions of literacy that pertain to the conversation at hand? How do I help him understand what Susan was saying, the extreme danger of undercutting teachers and teacher education while attempting to help?

Charles Vanover asked me to write him, to explain to him what I felt he did not understand. It is through writing this review, drawing on our artifacts from the performances, that I have learned how to frame my insights. As a result of his open-ended performance at the Ethnography in Education Forum, we got to this

place: What do these teacher stories help us understand about the dimensions of education and teaching that teacher educators need to address?

\section{Conclusion}

Teachers, educational administrators, teacher educators, and educational researchers all need better understandings of the complexities and dimensions of teaching, as do federal and state governments, as they are also involved in education. How can we use ethnodramatic inquiries around teachers' stories to support us in finding common ground? Having stood there that day after the Ethnography in Education Forum, locking eyes with Vanover, acutely aware of our different educational backgrounds, I now understand that we need ethnodramatic inquiries to help us invite multiple parties to engage in collaborative problem-solving from our various fields and positions engaged in schools and educational endeavors. We need participation structures that provide room for educators to bring their experiences to the conversation.

I have come to believe, however, that we cannot throw people into these conversations without any framing questions. Otherwise, the realities of teaching will be appropriated into dominant narratives about teachers as failing. Instead, we need to draw on teacher stories to help the public and all educators take up deeper inquiries into the intersections between teaching and society. We need to frame these inquiries by putting students, teachers, and multicultural critical pedagogy at their centers. We need to use ethnodrama to redirect dominant narratives that attack teachers as the problem and instead use teacher stories to illuminate the confluence of societal practices, institutional practices, and educational contexts.

The framing questions I would use for future ethnodramas on teachers' stories would be:

1. What do you hear in this teacher's narratives about their questions and goals for their practice?

2. How are those questions and goals related to the school and community contexts? 
3. What insights from each of our practices can we share with this teacher and with one another that would help the teacher in reaching their goals?

4. How are our insights related to our own locations within societal and educational contexts?

5. What can we learn from this teacher and from one another about the complexities of teacher education from these conversations?

6. How can we better articulate our goals for teacher education for a wider audience?

7. How do we make sense of the gap between our hopes for teachers' work and the challenging landscapes evoked by their narratives?

Charles Vanover helped the teachers who participated in his study to tell honest stories about students, lessons, and schools. As an artist, he developed performances that allowed audiences to connect to that content and to the puzzles of teachers' lives. Who is responsible if the stories teachers tell are troubling to us? Why is it so challenging to work towards a common language and common ground when discussing the work of teaching and learning? If it is not only dialogue that we need, but as Dr. Susan Lytle tried to tell us, the right kind of dialogue, how will we work together to create that dialogue? And how can ethnodrama help us? 


\section{References}

Hobson, S. (2012). Fostering critical literacy with high school students through ethnodrama. (Doctoral dissertation). Retrieved from ProQuest.

AAl3509138

Lytle, S. L. \& Cochran-Smith, M. (1992). Teacher research as a way of knowing. Harvard Educational Review, 62(4), 447-474.

Part, A. (1977). Fratres [Recorded by Rudolf Werthen \& I Fiamminghi, the Orchestra of Flanders]. On Arvo Part Fratres [CD]. Beverly Hills, CA: Telarc.

Vanover, C. (2016). Inquiry theatre. Qualitative Inquiry, 22(4), 238-248.

Vanover, C. (2015). Listening to the silences: Stories of a teacher's first year. [Performance and Discussion]. 36th Annual Ethnography in Educational Research Forum, Graduate School of Education, University of Pennsylvania, Philadelphia, PA.

Vanover, C. (2014). Goodbye to all that!: An accomplished teacher's last year in the Chicago Public Schools. [Performance and Discussion]. 35th Annual Ethnography in Educational Research Forum, Graduate School of Education, University of Pennsylvania, Philadelphia, PA. 